\title{
AKTIFITAS HEPATOPROTEKTIF EKSTRAK ETANOL DAUN SIDAGURI (Sida rhombifolia L.) DILIHAT DARI RASIO BERAT HEPAR, NILAI SGPT-SGOT, DAN HISTOPATOLOGI HEPAR PADA TIKUS SPRAGUE DAWLEY YANG DIINDUKSI CCL $\mathrm{CL}_{4}$
}

\author{
HEPATOPROTECTIVE ACTIVITY OF EXTRACT ETHANOL \\ SIDAGURI LEAVES FROM RATIO HEPAR WEIGHT, SGPT-SGOT \\ AND HISTOPATHOLOGIC OF HEPAR IN SPRAGUE DAWLEY RATS \\ INDUCED BY CCL 4
}

\author{
Lalu Muhammad Irham*, Wahyu Widyaningsih \\ Fakultas Farmasi Universitas Ahmad Dahlan \\ Jl. Prof. Dr. Soepomo, Janturan, Yogyakarta, Telp. (0274) 379418 \\ *Penulis Korespondensi, e-mail: lalu.irham@pharm.uad.ac.id
}

\begin{abstract}
ABSTRAK
Hepar merupakan organ yang berperan dalam pengaturan homeostasis tubuh meliputi metabolisme, biotransformasi, sintesis dan imunologi. Penyebab penyakit hepar bervariasi, diantaranya adalah virus, obat-obatan, alkohol dan stress oksidatif yang merupakan faktor utama. Jumlah radikal bebas yang melebihi antioksidan menyebabkan terjadinya stres oksidatif. Sidaguri (Sida rhombifolia L.) mengandung senyawa fenol dan flavonoid yang berkhasiat sebagai antioksidan. Penelitian ini bertujuan untuk menguji efek hepatoprotektif ekstrak etanol daun sidaguri (EEDS) terhadap nilai SGPTSGOT, gambaran histopatologi hepar tikus dan rasio berat hepar yang diinduksi carbon tetrachloride $\left(\mathrm{CCl}_{4}\right)$. Dua puluh lima tikus dibagi menjadi 5 kelompok. Kelompok I merupakan kelompok normal yang hanya diberi makan dan minum, kelompok II merupakan kelompok kontrol yang diinjeksi $\mathrm{CCl}_{4}$ secara intraperitoneal dengan dosis 1 $\mathrm{mL} / \mathrm{KgBB}$ dan kelompok (III, IV dan V merupakan kelompok perlakuan yang diberi EEDS peroral dengan dosis: 25, 50 dan $100 \mathrm{mg} / \mathrm{KgBB}$ ) berturut-turut selama 21 hari. Pada hari ke 21 kelompok ini diinjeksi $\mathrm{CCl}_{4} 1 \mathrm{~mL} / \mathrm{KgBB}$ secara intraperitoneal 1 jam setelah perlakuan. Data rasio berat organ hepar dari masing masing kelompok dianalisis secara statistik menggunakan analisis varian (ANOVA), LSD post hoc test $\mathrm{P}<0,05$ untuk menentukan perbedaan signifikan. Hasil penelitian menunjukkan bahwa rasio berat hepar pada kelompok II (kontrol) 216,52 $\pm 15,04$ berbeda signifikan dibandingkan dengan kelompok III, IV dan V berturut turut dengan nilai 436,56 \pm 46,78; $438,86 \pm 44,79$; dan 534,46 $\pm 45,49$. Hal ini menunjukkan bahwa pemberian EEDS dapat menaikkan rasio berat hepar. Data ini didukung dengan nilai SGPT dan SGOT yang berbeda bermakna dengan kelompok kontrol $(\mathrm{p}<0,05)$. Dilihat dari gambaran histopatologi hepar, pada kelompok II (kontrol), III, IV dan V berturut-turut tidak menunjukkan adanya nekrosis karena $\mathrm{CCl}_{4}$. Kesimpulan dari penelitian ini bahwa EEDS dapat melindungi hepar berdasarkan rasio berat hepar dan nilai SGPT-SGOT, namun belum dapat disimpulkan bahwa EEDS memiliki efek hepatoprotektif dilihat dari gambaran histopatologi.
\end{abstract}

Kata kunci : sida rhombifolia $\mathrm{L} .$, hepatoprotektor, $\mathrm{CCl}_{4}$, histopatologik 


\section{ABSTRACT}

Hepar is an important organ for homeostases such as metabolism, biotransformation, synthetic, and immunologic system. Many causes in pathogenesis of hepar such as virus, drugs, alcohol, and oxidative stress as the main factor. The number of radical scavenging much more than antioxidant leading the oxidative stress. Sidaguri (Sida rhombifolia L.) has phenolic and flavonoid compounds, which possess antioxidant activity. The aims of this study is to determined the effect of ethanol extract of sidaguri leaves asses by Sprague Dawley rats induced by carbon tetrachloride $\left(\mathrm{CCl}_{4}\right)$. Twentyfive rats divided into 5 groups. Group, I treated with aquades as normal, group II treated with a single dose of $\mathrm{CCl}_{4}(1 \mathrm{~mL} / \mathrm{Kg} \mathrm{BW}$ i.p $)$, group III, IV and V were treated with Sida rhombifolia extract 21 days $(25,50$ and $100 \mathrm{mg} / \mathrm{Kg}$ BW p.o) respectively. And administered with $\mathrm{CCl}_{4} 1 \mathrm{~mL} / \mathrm{Kg} B W 1$ hours after treated with Sida rhombifolia. Statistical analysis was carried out using the one-way analysis of variance (ANOVA), with LSD post hoc test to compare group mean and $P<0.05$ was considered statistically significant. The result showed ratio of hepar weight at Group group II (control) $216.52 \pm 15.04$ had significant difference comparing with III, IV and V group $436.56 \pm 46.78,438.86 \pm 44.79$ and $534.46 \pm 45.49$ consecutively. This study showed that ethanol extract of sidaguri leaves doses of 25,50 and $100 \mathrm{mg} / \mathrm{Kg} B W$ had hepatoprotective by increase the ratio of hepar. This also emphesized by SGPT and SGOT parameter were significant difference in compare to II Group ( $p<0.05$ ). The histopatological view of hepar rats showed that group II as control, III, IV and V group does not appear to caused necrosis by $\mathrm{CCl}_{4}$. The conclusion of this study, the ethanol extract of sidaguri leaf has hepatoprotective effect of hepar based on ratio of hepar and SGPT-SGOT. Conversely with histopatologic view that ethanol extract of sidaguri leaf did not associated with a hepatoprotective effect.

Keywords : Sida rhombifolia L, hepatoprotector, $\mathrm{CCl}_{4}$, histology

\section{PENDAHULUAN}

Hepar merupakan organ yang sangat penting dalam pengaturan homeostasis tubuh meliputi metabolisme, biotransformasi, sintesis, penyimpanan dan imunologi. Hepar melakukan banyak fungsi penting yang berbeda-beda dan bergantung pada sistem aliran darahnya yang unik dan sel-selnya yang sangat khusus. Ketika hepar rusak, maka semua sistem tubuh terpengaruh. Sel-sel hepar mempunyai kemampuan regenerasi yang cepat. Oleh karena itu sampai batas tertentu, hepar dapat mempertahankan fungsinya bila terjadi gangguan ringan. Pada gangguan yang lebih berat, terjadi gangguan fungsi yang serius yang dapat berakibat fatal (Corwin, 2009).

Sel-sel hepar sering sekali mengalami kerusakan. Kerusakan sel-sel hepar dapat disebabkan karena infeksi bakteri, virus, pemberian obat atau karena kanker dan bisa karena konsumsi alkohol serta zat-zat kimia. Kerusakan sel-sel hepar dapat berupa 
peradangan (hepatitis) ataupun kematian sel-sel hepar (nekrosis) (Underwood, 1999). Salah satu faktor yang dapat menyebabkan kerusakan pada hepar adalah karena stres oksidatif. Stres oksidatif adalah ketidakseimbangan antara radikal bebas atau prooksidan dan antioksidan yang dipicu oleh adanya dua kondisi di mana jumlah radikal bebas di dalam tubuh melebihi kapasitas tubuh untuk menetralkannya (Benhar et al., 2002).

Carbon tetrachloride $\left(\mathrm{CCl}_{4}\right)$ merupakan senyawa yang dapat menyebabkan stres oksidatif dan sering digunakan sebagai penginduksi kerusakan hepar (Panjaitan et al., 2007). $\mathrm{CCl}_{4}$ tertimbun secara besar-besaran dalam lemak tubuh, hepar dan sumsum tulang belakang (Klassen, 2001) dan diaktifkan oleh enzim sitokrom P-450 menjadi radikal triklorometil peroksi $\left(\mathrm{CCl}_{3} \mathrm{O}_{2} *\right)$ yang reaktivitasnya tinggi. Radikal yang dihasilkan dapat menyebabkan autooksidasi pada asam lemak yang terdapat dalam membran sel. Maka dari itu, $\mathrm{CCl}_{4}$ dapat menyebabkan nekrosis berat pada bagian sentrolobuler hepar yang mengandung isoenzim sitokrom P-450 dengan konsentrasi tertinggi (Hodgson dan Levi, 2002).

Sering kali suatu penyakit timbul karena ketidakseimbangan antara stress oksidatif dan pertahanan antioksidan, maka untuk mengurangi kerusakan jaringan oleh oksidatif tersebut diperlukan sebuah pencegahan dengan suplemen antioksidan (Narendhirakannan dan Limmy, 2010). Potensi terapi antioksidan alami harus mencakup enzim antioksidan yang mengikat radikal bebas atau agen yang mampu meningkatkan aktivitas enzim tersebut.

Salah satu tanaman yang mengandung senyawa yang memiliki aktivitas antioksidan adalah sidaguri (Sida rhombifolia L ). Kapasitas total antioksidan sidaguri setara dengan asam askorbat. Jumlah komponen fitokimia pada daun, batang, dan akar sidaguri, menunjukkan bahwa tanaman ini kaya akan flavonoid, tanin, fenol, steroid, glikosida, saponin dan terpenoid sampai batas tertentu. Senyawa fenolik dikenal sebagai agen antioksidan, yang bertindak sebagai terminator radikal bebas dan diketahui memiliki aktivitas medis dengan menunjukkan fungsi fisiologis. Senyawa seperti flavonoid yang mengandung hidroksil bertanggung jawab pada pengikatan radikal dari sebagian besar tanaman. Mekanisme aksi flavonoid adalah dengan proses pengikatan atau pembentukan khelat. Akar, batang dan daun Sida rhombifolia L. merupakan sumber potensial antioksidan alami (Narendhirakannan dan Limmy, 2010). 
Berdasarkan uraian di atas, serta didukung dari penelitian sebelumnya maka perlu dikaji efek hepatoprotektif ekstrak etanol daun sidaguri (EEDS) terhadap rasio berat organ hepar dan gambaran histopatologik hepar tikus Sprague Dawley yang diinduksi dengan $\mathrm{CCl}_{4}$.

\section{METODE PENELITIAN}

Penelitian ini menggunakan rancangan penelitian True Experimental Design-Post Test Only Control Group Design yaitu rancangan yang digunakan untuk mengukur efek setelah diberikan perlakuan pada kelompok kontrol dan perlakuan yang dikondisikan secara identik dan telah dikendalikan berbagai variabel yang tidak dikehendaki. Pada kelompok-kelompok tertentu diberikan intervensi sebagai cause sedangkan kelompok yang lain tidak diberikan intervensi, kemudian dibandingkan efek yang terjadi antara kelompok-kelompok tersebut (Yanwirasti, 2008).

\section{Alat dan Bahan}

Alat yang digunakan berupa alat maserasi, penangas air, spuit, alat-alat gelas, alat bedah, timbangan satu lengan, timbangan analitik. Bahan yang digunakan berupa daun sidaguri yang diperoleh dari Merapi Farma Yogyakarta, tikus putih betina galur SD umur 1,5 bulan dengan berat badan $\pm 80 \mathrm{~g}$ diperoleh dari LPPT UGM, etanol $96 \%$, CMC-Na $1 \%, \mathrm{CCl}_{4}$ sebagai bahan penginduksi hepatotoksik, minyak zaitun (pelarut $\mathrm{CCl}_{4}$ ), formalin $10 \%$, hematoksilin eosin, larutan xylol, $\mathrm{NaCl}$ fisiologis, akuades.

\section{Jalannya Penelitian}

Pembuatan ekstrak

Daun sidaguri sebanyak $3 \mathrm{Kg}$ dikeringkan di bawah sinar matahari dengan ditutupi kain hitam lalu dirajang hingga terbentuk serbuk kasar. Serbuk kasar $350 \mathrm{~g}$ dimaserasi dengan 2 L etanol 96\% sambil diaduk dengan magnetik stirer selama 1 jam dan didiamkan selama 2 hari kemudian disaring. Maserat yang diperoleh diuapkan dengan penangas air sampai diperoleh ekstrak kental. Suspensi EEDS dibuat dengan mencampur EEDS dengan CMC-Na 1\% yang dibuat dalam tiga variasi dosis yaitu 25, 50 dan 100 mg/KgBB. 
Pembuatan larutan $\mathrm{CCl}_{4}$

Pembuatan larutan $\mathrm{CCl}_{4}$, dibuat dengan cara mencampur $\mathrm{CCl}_{4}$ dengan minyak zaitun dengan perbandingan $1: 1$ (Sreelatha et al., 2009).

\section{Perlakuan Hewan Uji}

Hewan uji yang digunakan pada penelitian ini adalah tikus putih galur SD (Sprague Dawley) umur 1,5 bulan. Tikus tersebut diadaptasikan terlebih dahulu dengan lingkungan penelitian selama 1 minggu. Dua puluh lima ekor tikus dibagi dalam 5 kelompok, masing-masing kelompok terdiri dari 5 ekor tikus. Kelompok tersebut antara lain :

1. Kelompok I (normal) : diberi makan dan minum selama 21 hari.

2. Kelompok II (kontrol) : diberi makan, minum dan CMC-Na 1\% secara peroral selama 21 hari, kemudian pada hari ke 21 diinduksi $\mathrm{CCl}_{4} 1 \mathrm{~mL} / \mathrm{KgBB}$ secara intraperitoneal 1 jam setelah perlakuan.

3. Kelompok III : diberi makan, minum, dan suspensi ekstrak etanol daun sidaguri (EEDS) dosis $25 \mathrm{mg} / \mathrm{KgBB} /$ hari secara peroral selama 21 hari, kemudian pada hari ke 21 diinduksi $\mathrm{CCl}_{4} 1 \mathrm{~mL} / \mathrm{KgBB}$ secara intraperitoneal 1 jam setelah perlakuan.

4. Kelompok IV : diberi makan, minum dan suspensi (EEDS) dosis $50 \mathrm{mg} / \mathrm{KgBB} / \mathrm{hari}$ secara peroral selama 21 hari, kemudian pada hari ke 21 diinduksi $\mathrm{CCl}_{4} 1 \mathrm{~mL} / \mathrm{KgBB}$ secara intraperitoneal 1 jam setelah perlakuan.

5. Kelompok V : diberi makan, minum, dan suspensi EEDS dosis $100 \mathrm{mg} / \mathrm{KgBB} / \mathrm{hari}$ secara peroral selama 21 hari, kemudian pada hari ke 21 diinduksi $\mathrm{CCl}_{4} 1 \mathrm{~mL} / \mathrm{kgBB}$ secara intraperitoneal 1 jam setelah perlakuan.

Pada hari ke 21 semua hewan uji dipuasakan selama 24 jam kemudian pada hari k 22 tikus dikorbankan untuk dibedah dan diambil organ heparnya.

Penentuan Rasio Berat Organ Hepar

Rasio berat badan terhadap berat organ dengan menggunakan rumus penentuan rasio berat organ (Thomas, 1998):

$$
\mathrm{RBO}=\mathrm{BB} / \mathrm{BO}
$$

Keterangan: $\mathrm{RBO}=$ Rasio berat organ, $\mathrm{BB}=$ berat badan tikus, $\mathrm{BO}=$ berat organ tikus 
Preparasi Histopatologik Hepar

Hepar tikus dari masing-masing kelompok yang sudah diambil kemudian disimpan di dalam wadah yang berisi larutan formalin $10 \%$. Proses yang dilakukan untuk membuat preparat histopatologik hepar, dilakukan di Laboratorium Patologi Fakultas Kedokteran Hewan UGM Yogyakarta. Pemeriksaan selanjutnya dilakukan di bawah mikroskop binokuler di Laboratorium Diagnostik Fakultas Kedokteran Hewan UGM Yogyakarta dengan pembesaran 400 kali. Hasil langsung terekam di komputer.

Analisis data

Data rasio berat organ hepar dan nilai SGPT-SGOT dari masing masing kelompok dianaliasis secara statistik menggunakan analisis varian (ANOVA), LSD post hoc test $\mathrm{P}<0,05$ untuk menentukan perbedaan signifikan. Gambaran histopatologik hepar dianalisis secara deskriptif dengan membandingkan antar kelompok kontrol $\mathrm{CCl}_{4}$ dengan kelompok normal, dan kelompok EEDS dosis 25, 50 dan 100 mg/Kg BB.

\section{HASIL DAN PEMBAHASAN}

Pada penelitian ini efek hepatoprotektif EEDS dilihat dari parameter yaitu rasio berat badan terhadap berat organ hepar tikus (rasio berat hepar), nilai SGPT-SGOT dan gambaran histopatologik hepar tikus. Pada penentuan rasio berat badan terhadap organ hepar ini dengan membandingkan berat badan tikus terhadap organ hepar sehingga apabila berat heparnya semakin berat, maka akan menghasilkan nilai rasio berat organ hepar yang kecil. Parameter selanjutnya dengan melihat aktivitas SGPT dan SGOT serum darah tikus yang telah diinduksi $\mathrm{CCl}_{4}$. Tikus diberi suspensi EEDS selama 21 hari sebelum diinduksi $\mathrm{CCl}_{4}$ disebabkan karena kerusakan hati bersifat irreversibel, sehingga pengobatan yang dapat dilakukan adalah pengobatan preventif atau pencegahan.

Parameter ketiga adalah gambaran histopatologik hepar. Dari gambaran histopatologik ini akan terlihat seberapa besar kerusakan hepar tikus dan kemampuan EEDS sebagai hepatoprotektor. Kemampuan EEDS sebagai hepatoprotektor dapat dilihat dari kerusakan hepar dari gambaran histopatologik kelompok perlakuan dibandingkan dengan kelompok kontrol. Rerata rasio berat hepar tersaji pada Tabel I. 
Tabel I. Data rerata rasio berat hepar (rerata \pm SD) tikus pada masing-masing kelompok

\begin{tabular}{lccrc}
\hline Kelompok & $\begin{array}{c}\text { Dosis EEDS } \\
(\mathbf{m g} / \text { KgBB })\end{array}$ & $\begin{array}{c}\text { Rata rata } \\
\text { berat hepar } \\
(\mathbf{m g})\end{array}$ & $\begin{array}{c}\text { Rata rata } \\
\text { berat } \\
\text { badan(gram) }\end{array}$ & $\begin{array}{c}\text { Rata-rata rasio } \\
\text { berat hepar }\end{array}$ \\
\hline Normal & - & 186,02 & 109,04 & $587,32 \pm 61,47^{\mathrm{a}}$ \\
Kontrol & - & 334,07 & 72,47 & $216,52 \pm 15,05^{\mathrm{b}}$ \\
EEDS & 25 & 193,04 & 84,28 & $436,56 \pm 46,78^{\mathrm{a}}$ \\
EEDS & 50 & 200,52 & 88.00 & $438,86 \pm 44,79^{\mathrm{a}}$ \\
EEDS & 100 & 191,02 & 102,09 & $534,46 \pm 45,49^{\mathrm{a}}$ \\
\hline
\end{tabular}

Keterangan: Huruf (a) menunjukkan bahwa kelompok normal dan huruf (b) menunjukkan EEDS berbeda signifikan dengan kelompok kontrol

Kelompok normal mempunyai berat hepar lebih kecil dan rasio hepar tikus lebih besar $(587,32 \pm 61,47)$ jika dibandingkan dengan kelompok kontrol $(216,52 \pm 15,05)$. Pada kelompok normal berat hepar lebih kecil dan nilai rasio hepar lebih besar hal ini menunjukkan tidak terjadi kerusakan hepar. Dari hasil analisis statistik menunjukkan kelompok normal berbeda signifikan 0,009 $(\mathrm{p}<0,05)$ dengan kelompok kontrol. Hal ini membuktikan bahwa pemberian $\mathrm{CCl}_{4}$ memiliki efek toksik terhadap hepar tikus yang ditandai dengan meningkatnya berat hepar. Peningkatan berat hepar ini dapat terjadi karena kerusakan sel-sel hepar baik berupa nekrosis, degenerasi dan hepatitis (Raymond et al., 1983). Raymond et al., menyebutkan, pemberian $\mathrm{CCI}_{4}$ pada hewan coba akan menyebabkan terjadinya kerusakan hepar yang berujung pada kematian sel atau nekrosis. Kerusakan oleh $\mathrm{CCl}_{4}$ disebabkan karena adanya gangguan sintesis lipoprotein (VLDL) yang berfungsi sebagai alat transpor lipid dalam tubuh. Beberapa hal yang dapat menyebabkan kerusakan hepar adalah hipoksemi karena hepar tidak dapat membakar lemak, atau karena adanya toksin yang mengakibatkan penurunan fungsi lipolitik hepar dan terjadi penimbunan lipid intrasel sehingga sitoplasma tampak bervakuola dan menimbukan kematian sel berupa nekrosis (Ressang, 1984).

Berat hepar dan nilai rasio berat hepar berturut-turut pada kelompok dosis 25 $(436,56 \pm 46,78)$, dosis $50(438,86 \pm 44,79)$ dan dosis $100 \mathrm{mg} / \mathrm{KgBB}(534,46 \pm 45,49)$ jika dibandingkan dengan kelompok kontrol $(216,52 \pm 15,05)$ mempunyai berat hepar lebih kecil dan nilai berat organ hepar lebih besar dibanding kelompok kontrol. Hal ini 
menunjukkan kerusakan hepar pada kelompok kontrol lebih besar dibanding kelompok yang diberi EEDS. Berdasarkan analisis statistik terdapat perbedaan yang signifikan $(\mathrm{p}<$ 0,05) antara kelompok perlakuan EEDS dengan kelompok kontrol. Hal ini menunjukkan bahwa kelompok dosis 25, 50 dan $100 \mathrm{mg} / \mathrm{KgBB}$ berpengaruh terhadap pencegahan peningkatan berat hepar. Pada kelompok dosis $25 \mathrm{mg} / \mathrm{KgBB}(436,56 \pm$ 46,78), jika dibandingkan dengan kelompok dosis $50 \mathrm{mg} / \mathrm{KgBB}(438,86 \pm 44,79)$ tidak mempunyai perbedaan yang signifikan 0,917 ( $\mathrm{p}>0,05)$. Hal ini menunjukkan bahwa pemberian EEDS dengan dosis 25 dan $50 \mathrm{mg} / \mathrm{KgBB}$ memiliki efek yang sama terhadap rasio berat hepar.

Pada kelompok dosis $100 \mathrm{mg} / \operatorname{KgBB}(534,46 \pm 45,49)$ rasio berat heparnya tidak berbeda signifikan ( $>>0,05)$ dengan kelompok normal $(587,32 \pm 61,47)$. Hal ini menunjukkan bahwa pemberian EEDS dengan dosis $100 \mathrm{mg} / \mathrm{KgBB}$ mampu mencegah peningkatan berat hepar tikus yang diinduksi $\mathrm{CCl}_{4}$. Perbedaan yang signifikan $(\mathrm{p}<0,05)$ juga terlihat jika kelompok dosis $100 \mathrm{mg} / \mathrm{KgBB}(534,46 \pm 45,49)$ dibandingkan dengan kelompok dosis $25 \mathrm{mg} / \mathrm{KgBB}(436,56 \pm 46,78)$ dan kelompok dosis $50 \mathrm{mg} / \mathrm{kgBB}$ $(438,86 \pm 44,79)$. Hal ini menunjukkan bahwa peningkatan dosis pemberian EEDS sampai $100 \mathrm{mg} / \mathrm{KgBB}$ memberikan efek yang lebih besar jika dibandingkan dengan kelompok dosis 25 dan $50 \mathrm{mg} / \mathrm{KgBB}$. Data ini didukung oleh hasil pengukuran alkaline phosphatase ALP oleh Hanifa (2012), menyimpulkan bahwa kemampuan EEDS dalam menurunkan aktivitas ALP serum tikus semakin meningkat sebanding dengan peningkatan dosisnya. Berdasarkan hasil penelitian ini dapat disimpulkan dari parameter rasio berat badan terhadap berat hepar, semakin besar dosis EEDS yang diberikan, kemampuannya dalam melindungi hepar semakin besar. Hal ini dapat dilihat dari semakin besarnya rasio organ hepar yang menunjukkan kerusakan hepar semakin kecil. Dari gambaran histopatologik hepar bahwa $\mathrm{CCl}_{4}$ yang digunakan sebagai penginduksi kerusakan hepar tidak menimbulkan nekrosis pada hepar, sehingga belum dapat diambil kesimpulan bahwa EEDS mempunyai efek hepatoprotektif terhadap adanya radikal bebas $\mathrm{CCl}_{4}$. Data histopatologik hepar tikus pada masing-masing kelompok tersaji pada Tabel II. 
Tabel II. Data histopatologik hepar tikus masing-masing kelompok

\begin{tabular}{|c|c|c|c|}
\hline Kelompok & Dosis (mg/KgBB) & Tikus & Hasil Pengamatan \\
\hline \multirow{5}{*}{ Normal } & \multirow{5}{*}{ - } & 1 & Normal \\
\hline & & 2 & Normal \\
\hline & & 3 & MFN \\
\hline & & 4 & FN \\
\hline & & 5 & Normal \\
\hline \multirow{5}{*}{ Kontrol } & \multirow{5}{*}{$1 \mathrm{~mL} / \mathrm{KgBB}$} & 1 & DM,PH \\
\hline & & 2 & PH \\
\hline & & 3 & PH \\
\hline & & 4 & $\mathrm{FN}, \mathrm{PH}$ \\
\hline & & 5 & PH \\
\hline \multirow{5}{*}{ EEDS } & \multirow{5}{*}{$25 \mathrm{mg} / \mathrm{KgBB}$} & 1 & PH \\
\hline & & 2 & MFN \\
\hline & & 3 & Normal \\
\hline & & 4 & MFN,PH \\
\hline & & 5 & PH \\
\hline \multirow{5}{*}{ EEDS } & \multirow{5}{*}{$50 \mathrm{mg} / \mathrm{KgBB}$} & 1 & PH \\
\hline & & 2 & PH \\
\hline & & 3 & MFN, PH \\
\hline & & 4 & PH \\
\hline & & 5 & PH \\
\hline \multirow{5}{*}{ EEDS } & \multirow{5}{*}{$100 \mathrm{mg} / \mathrm{KgBB}$} & 1 & Normal \\
\hline & & 2 & PH,A \\
\hline & & 3 & PH \\
\hline & & 4 & PH \\
\hline & & 5 & PH \\
\hline
\end{tabular}

Keterangan : $\quad \mathrm{DM}=$ Degenerasi melemak, $\mathrm{FN}=$ Foki Nekrotik, MFN $=$ Multi fokal nekrotik, $\mathrm{PH}=$ Perihepatits, $\mathrm{A}=$ Atropi hepatosit

Berdasarkan hasil analisis histopatologik, kelompok normal mengalami multi fokal nekrotik dan fokal nekrotik. Hal ini kemungkinan disebabkan oleh faktor bakterial yang berasal dari lingkungan, pakan dan minuman atau tikus pada saat perlakuan. Seharusnya pada kelompok normal tidak terjadi nekrosis karena tidak diinjeksi $\mathrm{CCl}_{4}$. Berbanding terbalik dengan kelompok yang hanya diinjeksi $\mathrm{CCl}_{4}$ dapat menyebabkan nekrosis yang hebat di sentrolobuler hepar yang mengandung isoenzim sitokrom P-450 dengan konsentrasi tertinggi (Hodgson and Levi, 2002). Hasil penelitian ini nekrosis terjadi di tepi, terlihat pada gambar 7 dimana intinya memekat di tepi atau dikenal dengan piknosis.

Kelompok kontrol mengalami kerusakan berupa foki nekrotik, degenerasi melemak (vakuoler) serta perihepatitis. Nekrosis merupakan kematian sel atau jaringan pada organisme hidup (Underwood, 1999). Peristiwa ini ditandai dengan inti sel yang 
mengkerut dan menjadi gelap sampai tidak ada lagi eukromatin (piknosis), kemudian terfragmentasi (karioreksis), kemudian menghilang (kariolisis). Kerusakan ini disebabkan karena efek toksik dari $\mathrm{CCl}_{4} \mathrm{CCl}_{4}$ di dalam tubuh akan dimetabolisme oleh sitokrom $\mathrm{P}_{450}$ menjadi radikal triklorometil $\left(\mathrm{CCl}_{3} *\right)$. Dengan adanya oksigen akan mempercepat reaksi terbentuknya radikal triklorometilperoksi $\left(\mathrm{CCl}_{3} \mathrm{O}_{2} *\right)$. Radikal bebas yang terbentuk menyebabkan peroksidasi lipid sehingga mengganggu homeostasis $\mathrm{Ca}^{2+}$. Terganggunya homeostasis $\mathrm{Ca}^{2+}$ menyebabkan hiperkalsemia intraseluler. Hal ini memacu peningkatan produksi senyawa oksigen reaktif atau Reactive Oxygen Species (ROS) yang dapat merusak unsur-unsur dalam mitokondria seperti fosfolipid dan protein sehingga menyebabkan kematian sel (Panjaitan et al., 2007).

Pada gambaran histopatologik hepar terlihat intinya memekat di tepi artinya nekrosis disebabkan bukan karena efek $\mathrm{CCl}_{4}$ tetapi disebabkan karena faktor bakterial dan faktor dosis $\mathrm{CCl}_{4}$ yang kurang memberikan efek nekrosis. Degenerasi vakuoler merupakan perubahan biokimia intraseluler disertai perubahan morfologik pada sel seperti akumulasi cairan dan sifatnya reversibel. Bentuk perubahan degeneratif sel berupa pembengkakan sel atau perubahan hidrofik dan penimbunan lipid intrasel sehingga menyebabkan kerusakan dalam sel dan terbentuknya ruangan yang luas dan terlihat kosong di bawah mikroskop (Raymond, 1983). Akibat dari terjadinya nekrosis dan degenerasi vakuoler ini fungsi hepar yang berangsur turun menjadi fokus infeksi (medium perkembangbiakan mikroorganisme tertentu), perubahan sistemik tertentu, misalnya leukositosis dan demam, serta pengeluaran enzim-enzim dalam hepar ke pembuluh darah, misalnya ditandai dengan meningkatnya kadar SGPT-SGOT dalam darah. Pada percobaan dengan pengukuran aktivitas SGPT-SGOT terlihat pada kelompok kontrol mengalami peningkatan SGPT dan SGOT paling tinggi dibanding kelompok yang lain. Hasil pengukuran aktivitas SGPT dan SGOT dapat dilihat pada Tabel III.

Pada kelompok EEDS dosis 25 dan $50 \mathrm{mg} / \mathrm{KgBB}$ hanya terdapat kelainan sel hepar yaitu multifokal nekrotik. Pada kelompok EEDS dosis $100 \mathrm{mg} / \mathrm{KgBB}$ terjadi kelainan pada sel hepar yaitu atropi dan perihepatitis. Perihepatitis terjadi kemungkinan besar disebabkan oleh bakteri yang berasal dari kurang bersihnya kandang dan minuman selama percobaan, karena pada minuman dapat tumbuh bakteri seperti E. coli yang dapat menyebabkan terjadinya hepatitis, maka kebersihan hal utama yang 
seharusnya menjadi perhatian khusus bagi seorang peneliti sehingga hasil percobaan nantinya dapat benar-benar memberikan hasil yang optimal sesuai dengan teori.

Tabel III. Hasil pengukuran aktivitas SGPT-SGOT serum darah

\begin{tabular}{cccc}
\hline Kelompok & $\begin{array}{c}\text { Dosis } \\
(\mathbf{m g} / \text { KgBB })\end{array}$ & \multicolumn{2}{c}{ Aktivitas (U/L) } \\
& & SGPT & SGOT \\
\hline Normal & - & $44,6 \pm 2,191$ & $119,84 \pm 18,237$ \\
Kontrol & - & $67 \pm 1,141$ & $262,7 \pm 21,640$ \\
EEDS & 25 & $42,2 \pm 6,979$ & $193,04 \pm 32,264$ \\
EEDS & 50 & $40,4 \pm 6,387$ & $191,02 \pm 45,253$ \\
EEDS & 100 & $57,75 \pm 8,098$ & $200,52 \pm 36,559$ \\
\hline
\end{tabular}

Pada dosis $100 \mathrm{mg} / \mathrm{KgBB}$ hanya terjadi perihepatitis dan atropi, sedangkan nekrosis tidak tampak. Pengukuran aktivitas SGPT merupakan tes fungsi hepar yang lebih sensitif untuk hepatitis yang disebabkan oleh senyawa toksin (Widmman, 1995). Hal ini mendukung data gambaran histopatologik hepar bahwa pada dosis 100 $\mathrm{mg} / \mathrm{KgBB}$ terjadi perihepatitis.

Data hasil pengukuran aktivitas SGPT dan SGOT tersebut dianalisis secara statistik dengan Post Hoc Test LSD dengan taraf kepercayaan 95\% (signifikansi=0,05) untuk mengetahui perbedaan antar kelompok. Hasil analisis tersebut dapat dilihat pada Tabel IV dan Tabel V.

Tabel IV. Hasil analisis aktivitas SGPT dengan Post Hoc Test LSD

\begin{tabular}{|c|c|c|c|c|c|}
\hline Kelompok & Normal & Kontrol & $\begin{array}{c}\text { EEDS } \\
\text { dosis } 25 \\
\mathrm{mg} / \mathrm{KgBB} \\
\end{array}$ & $\begin{array}{c}\text { EEDS } \\
\text { dosis 50 } \\
\text { mg/KgBB } \\
\end{array}$ & $\begin{array}{c}\text { EEDS } \\
\text { dosis } 100 \\
\text { mg/KgBB } \\
\end{array}$ \\
\hline Normal & - & & & & \\
\hline Kontrol & $0,000 *$ & - & & & \\
\hline $\begin{array}{c}\text { EEDS dosis } 25 \\
\mathrm{mg} / \mathrm{kgBB}\end{array}$ & $0,512 * *$ & $0,000^{*}$ & - & & \\
\hline $\begin{array}{c}\text { EEDS dosis } 50 \\
\mathrm{mg} / \mathrm{kgBB}\end{array}$ & $0,257 * *$ & $0,000^{*}$ & $0,622 * *$ & - & \\
\hline $\begin{array}{c}\text { EEDS dosis } 100 \\
\mathrm{mg} / \mathrm{kgBB}\end{array}$ & $0,003 *$ & $0,033^{*}$ & $0,001^{*}$ & $0,000 *$ & - \\
\hline
\end{tabular}

*Berbeda Signifikan $(\mathrm{p}<0,05)$

$* *$ Tidak Signifikan $(\mathrm{p}>0,05)$ 
Tabel V. Hasil analisis aktivitas SGOT dengan Post Hoc Test LSD

\begin{tabular}{|c|c|c|c|c|c|}
\hline Kelompok & Normal & Kontrol & $\begin{array}{c}\text { EEDS } \\
\text { dosis } 25 \\
\mathrm{mg} / \mathrm{KgBB} \\
\end{array}$ & $\begin{array}{c}\text { EEDS } \\
\text { dosis 50 } \\
\text { mg/KgBB } \\
\end{array}$ & $\begin{array}{c}\text { EEDS } \\
\text { dosis } 100 \\
\text { mg/KgBB } \\
\end{array}$ \\
\hline Normal & - & & & & \\
\hline Kontrol & $0,000 *$ & - & & & \\
\hline $\begin{array}{c}\text { EEDS dosis } 25 \\
\mathrm{mg} / \mathrm{kgBB}\end{array}$ & $0,002 *$ & $0,003 *$ & - & & \\
\hline $\begin{array}{c}\text { EEDS dosis } 50 \\
\mathrm{mg} / \mathrm{kgBB}\end{array}$ & $0,002 *$ & $0,002 *$ & $0,922 * *$ & - & \\
\hline $\begin{array}{c}\text { EEDS dosis } 100 \\
\mathrm{mg} / \mathrm{kgBB}\end{array}$ & $0,001 *$ & $0,006^{*}$ & $0,718^{* *}$ & $0,647 * *$ & - \\
\hline
\end{tabular}

*Berbeda Signifikan $(\mathrm{p}<0,05)$

$* *$ Tidak Signifikan $(\mathrm{p}>0,05)$

Secara teoritis efek hepatoprotektif dari ekstrak etanol daun sidaguri disebabkan karena kandungan antioksidannya. Antioksidan merupakan senyawa yang mampu menangkal radikal bebas yang masuk ke dalam tubuh (Winarsi, 2007). Sidaguri merupakan salah satu tanaman sebagai sumber potensial antioksidan alami. Salah satu senyawa antioksidan yang terkandung dalam tanaman sidaguri adalah flavonoid (Narendhirakannan dan Limmy, 2010). Flavonoid merupakan senyawa fenolik penangkap radikal bebas yang masuk ke dalam tubuh (Amic et al., 2003). Mekanisme aksi flavonoid adalah dengan cara pengikatan atau pembentukan khelat yang membuat radikal bebas tersebut menjadi senyawa yang tidak toksik sehingga radikal bebas tersebut tidak sampai merusak hepar (Amic et al., 2003). Hasil gambar hispatologik hepar tersaji pada Gambar 1-5.

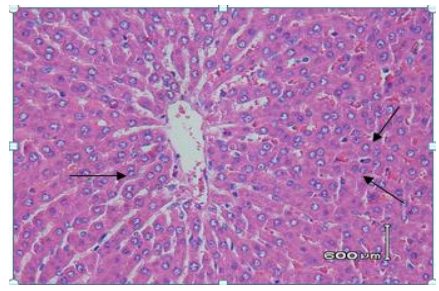

Gambar 1 : Gambar histopatologik hepar kelompok normal dengan perbesaran 400x. Tanda panah menunjukkan inti sel yang normal terlihat tidak ada perubahan yang spesifik dan inti selnya sama besar. Pengecatan menggunakan Hematoksilin dan Eosin. 


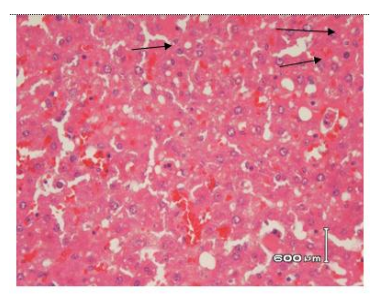

Gambar 2 : Gambar histopatologik hepar pada kelompok kontrol mengalami degenerasi melemak dengan perbesaran 400x. Tanda panah mengalami degenerasi vakuoler. Pengecatan menggunakan Hematoksilin dan Eosin.

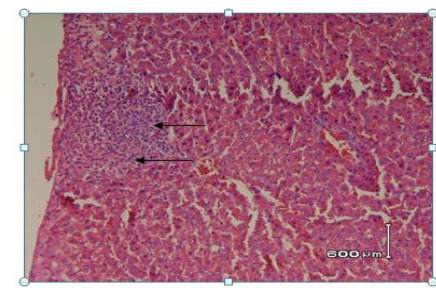

Gambar 3: Gambar histopatologik hepar nekrosis yang terjadi pada kelompok normal ,kontrol, Dosis EEDS $25 \mathrm{mg} / \mathrm{KgBB}, 50 \mathrm{mg} / \mathrm{kgBB}$ dengan perbesaran 400x. Tanda panah mengalami nekrosis, terlihat jelas inti sel mengkerut (piknosis). Pengecatan menggunakan Hematoksilin dan Eosin.

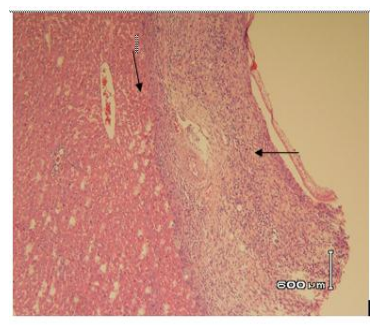

Gambar 4 :Gambar histopatologik hepar perihepatitis yang terjadi pada kelompok kontrol, dosis EEDS 25, 50 dan $100 \mathrm{mg} / \mathrm{KgBB}$ dengan perbesaran 400x. Tanda panah menunjukkan terjadinya perihepatitis ditandai dengan peradangan pada tepi hepar dan penebalan kapsula glissoni. Pengecatan menggunakan Hematoksilin dan Eosin.

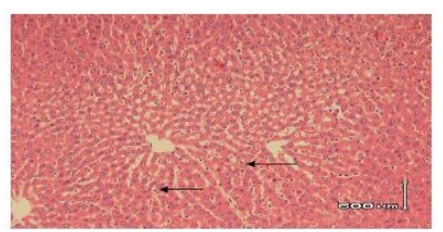

Gambar 5 : Gambaran histopatologik hepar atropi yang terjadi pada kelompok EEDS 100 $\mathrm{mg} / \mathrm{Kg} \mathrm{BB}$ dengan perbesaran 200x, ditandai dengan ukuran hepatosit yang lebih kecil dari normal sehingga terjadinya pelebaran ukuran sinusiod. Pengecatan menggunakan Hematoksilin dan Eosin. 
Gambar 1 merupakan gambaran histopatologik hepar kelompok normal. Di sana terlihat bahwa sel hepar masih tersusun rapi dan dengan ukuran sel yang sama. Pada Gambar 2 degenerasi vakuoler ditunjukkan dengan adanya rongga-rongga pada sel. Rongga-rongga ini terbentuk karena adanya penimbunan cairan atau lemak pada sel-sel hepar yang kemudian cairan atau lemak tersebut terlarut dalam pelarut organik yang digunakan dalam pembuatan preparat histopatologik. Gambar 3 merupakan gambaran histopatologik yang menunjukkan sel hepar mengalami nekrosis dimana terlihat jelas inti sel mengkerut dan memekat (piknosis). Sementara pada Gambar 4 merupakan gambaran histopatologik hepar yang mengalami perihepatitis, ditandai dengan peradangan pada tepi hepar dan penebalan kapsula glissoni. Gambar 5 menunjukkan gambaran histopatologik hepar yang mengalami atropi hepatosit, ditandai dengan ukuran hepatosit yang lebih kecil dari normal sehingga terjadinya pelebaran ukuran sinusiod.

\section{KESIMPULAN}

Kesimpulan dari penelitian ini bahwa EEDS dapat melindungi hepar berdasarkan rasio berat hepar dan nilai SGPT, SGOT. Dari gambaran histopatologik hepar EEDS tidak menunjukkan adanya gambaran efek hepatoprotektif.

\section{DAFTAR PUSTAKA}

Amic, D., Davidovic, D., Beslo, D., Trinajstic, N., 2003, Structure-Radical Scavenging Activity Relationships of Flavonoids, Croatia Chemica Acta, 76 (1) : 55-61.

Corwin, E.J., 2009, Buku Saku Patofisiologi, diterjemahkan oleh Subekti, N.B., 646655, EGC, Jakarta.

Benhar, M.,Engelberg D., Levistki A., 2002, Reactive Oxygen Species (ROS), stress activated konases and stress signaling in cancer, EMBO reports.;3(5):420-5.

Hanifa, I., 2012, Efek Hepatoprotektif Ekstrak Etanol Daun Sidaguri (Sida rhombifolia L) dengan parameter aktivitas alkaline phospatase (ALP) serum tikus galur 
Sprague dawley, Skripsi, Fakultas Farmasi Universitas Ahmad Dahlan, Yogyakarta.

Hodgson, E., Levi P.E., 2000, A Textbook of Modern Toxicology ,1999-2006, ${ }^{\text {th }}$ Edition.Boston: McGraw Hill Book Co.,Singapore

Narendhirakannan R.T., and Limmy T.P., 2010, In vitro Antioxidant Studies on Ethanolic Extracts of Leaf, Stem and Root of Sida rhombifolia L. International Journal of Pharmacology and Biochemical Sciences, V1(2).

Panjaitan, R.G.P., Handharyani, E., Chairul., Masriani., Zakiah, Z., dan Manalu, W., 2007, Pengaruh Pemberian Karbon Tetraklorida terhadap Fungsi Hepar dan Ginjal Tikus, Makara Kesehatan, (11) $1: 11-16$.

Raymond, FB., Kuldeep, P., James, ML.,1983, Reduced Glutathione Against Rat Liver Microsomal Injury by Carbon Tetrachloride, Biochemistry., 215:441-45.

Ressang, A.A., 1984, Patologi Khusus Veteriner, Ed ke-2. Bali: Percetakan Bali.

Sreelatha, S., Padma, P.R., Umadevi, M., 2009, Protective Effects of Coriandrum sativum Extracts on Carbon Tetrachloride-Induced Hepatotoxicity in Rats, Food and Chemical Toxicology, 47 : 702-708.

Thomas, L., 1998, Clinical laboratory diagnostic, (1st ed). Frankfrut: the Basic Verlagesell Schaft.

Underwood, J.C.E., 1999, Patologi Umum dan Sistematik, Edisi 2, diterjemahkan oleh Sarjadi, EGC, Jakarta, hal 470-471, 474.

Winarsi, H., 2007, Antioksidan Alami dan Radikal Bebas, Kanisius, Yogyakarta, hal $12,15,18,79-81$. 
Widmann, 1995, Tinjauan Klinis atas Hasil Pemeriksaan Laboratorium, EGC, Jakarta.

Yanwirasti, 2008, Langkah-Langkah Pokok Penelitian Biomedik, Padang: FK Universitas Andalas Padang. 